\title{
Systemic lupus erythematosus manifestation following COVID-19: a case report
}

\author{
Batool Zamani', Seyed-Masoud Moeini Taba ${ }^{2}$ and Mohammad Shayestehpour ${ }^{1,2^{*}}$
}

\begin{abstract}
Background: Systemic lupus erythematosus (SLE) is a complex and challenging autoimmune disease. Severe acute respiratory syndrome coronavirus 2 (SARS-CoV-2) is a novel viral agent that can cause a life-threatening respiratory disorder named coronavirus disease 2019 (COVID-19). Association between SARS-CoV-2 and SLE is not clear. We reported the first case of SLE manifestation following COVID-19.

Case presentation: A 39-year-old Iranian/Persian man with complaints of fever, scaling on the palms of the hands and feet, lower extremity edema, and ankle swelling was referred to Kashan Rheumatology Clinic in 2020. He was infected with SARS-CoV-2 2 months ago. The patient had proteinuria and was positive for SLE laboratory tests. After one week of treatment with prednisolone (30 mg daily) and hydroxychloroquine, paresthesia, proteinuria, and edema continued. The patient was treated with pulse methylprednisolone (1000 mg for three consecutive days), gabapentin, and vitamin B (300 mg daily), which reduced paresthesia.
\end{abstract}

Conclusions: This is the first case of SLE manifestation following COVID-19. SARS-CoV-2 may produce autoantibodies or develop the clinical features of subclinical SLE.

Keywords: Autoantibodies, Autoimmune diseases, COVID-19, Systemic lupus erythematosus

\section{Introduction}

Systemic lupus erythematosus (SLE) is an autoimmune disease characterized by the breaking of tolerance to nuclear self-antigens and the production of pathogenic autoantibodies. This complex and challenging disease can involve several organs in the body such as skin, eyes, kidney, heart, muscles, and the joints [1]. Previous studies reported that some viruses may be implicated in the etiology of SLE. Epstein-Barr virus (EBV) is as potential causal agent of SLE. In addition, cytomegalovirus, parvovirus $\mathrm{B} 19$, and retroviruses can be possible triggers for SLE. Immune reactions against viral antigens may turn against the self-antigens that can lead to autoimmunity (molecular mimicry) [2]. There are reports of several

*Correspondence: shayestehpour-m@kaums.ac.ir

${ }^{1}$ Autoimmune Diseases Research Center, Kashan University of Medical Sciences, Kashan, Iran

Full list of author information is available at the end of the article cases of SLE that have manifested following acute viral infections (Dengue fever virus) [3].

Severe acute respiratory syndrome coronavirus 2 (SARS-CoV-2) is a novel viral agent that has caused coronavirus disease 2019 (COVID-19). This acute viral infection is frequently associated with respiratory failure, pneumonia, acute respiratory distress syndrome (ARDS), and sepsis [4]. A fulminant increase in the serum proinflammatory cytokines including, IL-1, IL-6, IL-12, IFN- $\gamma$, TGF $\beta$, and chemokines such as CCL2, CXCL9, CXCL10 was detected in severe cases of COVID-19 [5]. Although a few case reports have been published on the possible association between coronavirus and autoimmune disorders, the role of this virus in autoimmunity is not clear [6]. To date, several cases have been reported patients with lupus who have been infected with COVID19 [7], but no data have been published on the onset of clinical manifestations of SLE after getting COVID-19. original author(s) and the source, provide a link to the Creative Commons licence, and indicate if changes were made. The images or other third party material in this article are included in the article's Creative Commons licence, unless indicated otherwise in a credit line to the material. If material is not included in the article's Creative Commons licence and your intended use is not permitted by statutory regulation or exceeds the permitted use, you will need to obtain permission directly from the copyright holder. To view a copy of this licence, visit http://creativecommons.org/licenses/by/4.0/. The Creative Commons Public Domain Dedication waiver (http://creativeco mmons.org/publicdomain/zero/1.0/) applies to the data made available in this article, unless otherwise stated in a credit line to the data. 
We reported the first case of SLE manifesting following COVID-19.

\section{Case presentation}

A 39-year-old Iranian/Persian man with complaints of fever $\left(38{ }^{\circ} \mathrm{C}\right)$, scaling on the palms of the hands and feet, lower extremity edema, and ankle swelling was referred to Kashan Rheumatology Clinic in 2020.

2 months ago, the patient was referred with complaints of fever, dry cough, shortness of breath, and wheezing. Upon arrival he had a high temperature $\left(38^{\circ} \mathrm{C}\right)$, a respiratory rate of 22 breaths per minute, a heart rate of 110 / min, a blood pressure of 100/70 and oxygen saturation of $93 \%$. The patient had no history of alcohol consumption and cigarette smoking. The result of laboratory tests showed leukopenia (white blood cell (WBC): $4200 / \mathrm{mm}^{3}$ ), thrombocytopenia (platelet count: $73,000 / \mathrm{mm}^{3}$ ), high C-reactive protein (CRP: $43 \mathrm{mg} / \mathrm{L}$ ), hemoglobinemia (hemoglobin level: $11.2 \mathrm{~g} / \mathrm{dL}$ ), and normal liver function tests.

Computed tomography (CT) of the chest showed two ground-glass opacity nodules in the lower lobes of both lungs (Fig. 1). SARS-CoV-2 was detected in the nasal swab by reverse-transcription polymerase chain reaction test (RT-PCR). The patient did not need intensive care unit (ICU) admission and underwent outpatient treatment for COVID-19. He was treated with $400 \mathrm{mg}$ oral dose of hydroxychloroquine twice on the first day and $200 \mathrm{mg}$ twice daily for an additional 6 days.

The patient recovered after 4 weeks, but gradually, urticaria-like skin lesions and erythematous rashes appeared on the chest, upper and lower limbs with itching. The patient developed scaling on the palms of the hands and feet and hyperkeratosis of the soles of the feet. Lower extremity edema and ankle swelling were also added to the complications of the disease. The patient suffered from a weight loss of about $15 \mathrm{~kg}$, anorexia, and headache during 2 months. He was suffering from hyperesthesia of lower extremity on both sides when referred to the rheumatology clinic. He felt severe burning and pain when his feet were touched. The tendon reflexes and strength of the lower and upper limbs were normal. The results of primary laboratory tests were as follows: platelet count, $73,000 / \mathrm{mm}^{3}\left(150,000-400,000 / \mathrm{mm}^{3}\right)$; white blood cell count, $4200 / \mathrm{mm}^{3}\left(4500-11,000 / \mathrm{mm}^{3}\right)$; $(14-18 \mathrm{~g} / \mathrm{dL})$; C-reactive protein (CRP) level, $34 \mathrm{mg} / \mathrm{L}(<10 \mathrm{mg} / \mathrm{L})$; erythrocyte sedimentation rate (ESR), $74 \mathrm{~mm} /$ hour $(0-20$ $\mathrm{mm} /$ hour); lactate dehydrogenase (LDH), $437 \mathrm{U} / \mathrm{L}$ (150$450 \mathrm{U} / \mathrm{L})$; troponin I, $3 \mu \mathrm{g} / \mathrm{L}(<0.03 \mu \mathrm{g} / \mathrm{L})$. Electrolytes, kidney and liver function tests were normal.

Due to the observation of bicytopenia, the patient's peripheral blood smear (PBS) was evaluated by a hematologist. Toxic granulation was observed in the PBS while blast cells and schistocytes were not seen. Patient had a normal echocardiogram. SARS-CoV-2 genome was not detected by RT-PCR. IgG antibodies against SARS$\mathrm{CoV}-2$ were detectable by the enzyme-linked immunosorbent assay (ELISA) (Pishtaz Teb Zaman, Tehran, Iran), but IgM antibodies against SARS-CoV-2 were negative (Pishtaz Teb Zaman, Tehran, Iran) in the serum sample. Urine analysis showed $2+$ proteinuria and $550 \mathrm{mg}$ of protein was measured in the 24-h urine sample. Electromyography (EMG) and nerve conduction velocity (NCV) showed motor and sensory polyneuropathies.

The patient was suspected of having SLE. The results of laboratory tests to diagnosis systemic lupus
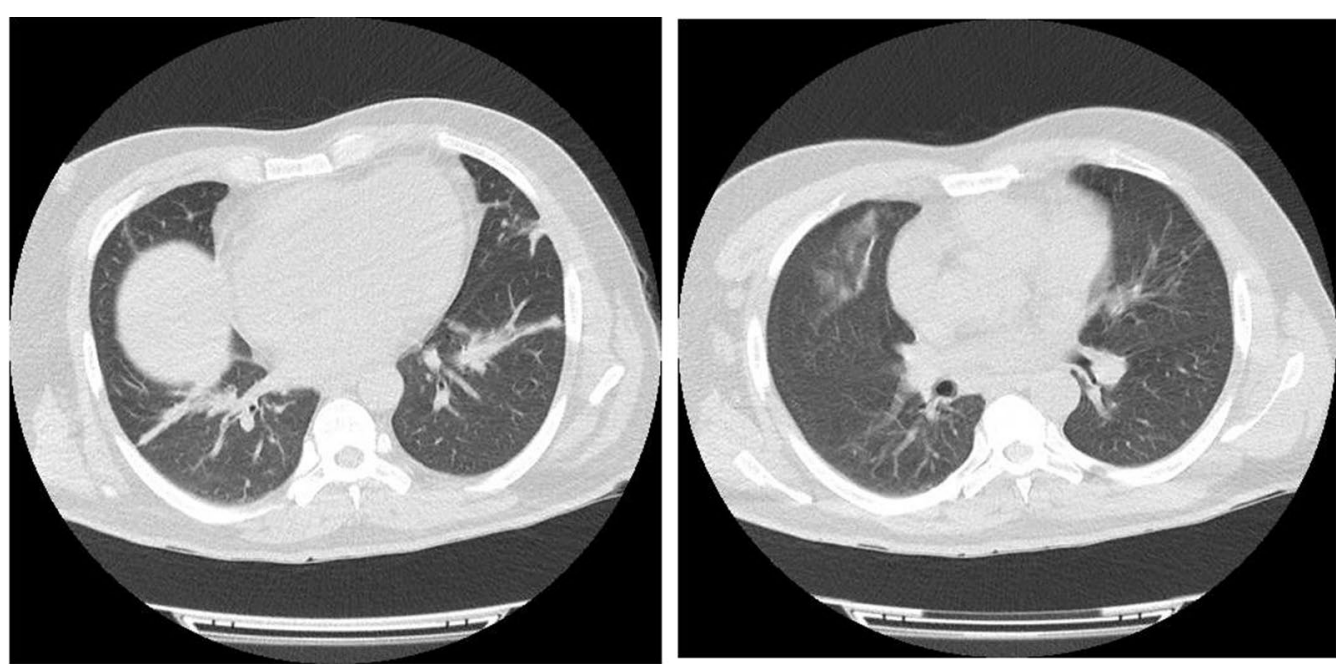

Fig. 1 Chest computed tomography images of the patient with COVID-19. Ground-glass opacity nodules are seen in the lower lobes of both lungs 
erythematosus are as follows: total complement activity (CH50), 45 (50-150); complement C3 protein, 133 $\mathrm{mg} / \mathrm{dL}(90-180 \mathrm{mg} / \mathrm{dL})$; complement $\mathrm{C} 4$ protein, 14 $\mathrm{mg} / \mathrm{dL}$ (10-40 mg/dL); anti-La/SSB antibodies, $160 \mathrm{U} /$ $\mathrm{ml}(<12 \mathrm{U} / \mathrm{mL})$; anti-SSA/Ro, $200 \mathrm{U} / \mathrm{mL}(<25 \mathrm{U} / \mathrm{mL})$; anti-cyclic citrullinated peptides (anti-CCP) antibodies, $48 \mathrm{IU} / \mathrm{mL}(<20 \mathrm{IU} / \mathrm{mL})$; anti-double-stranded deoxyribonucleic acid antibody (anti-dsDNA), $70 \mathrm{IU} /$ $\mathrm{mL}(<35 \mathrm{IU} / \mathrm{mL})$; fluorescence antinuclear antibody (FANA), 1/160. Anticardiolipin, lupus anticoagulant, anti-beta-2 glycoprotein 1, and anti-neutrophil cytoplasmic antibodies (C-ANCA, P-ANCA) were negative. The patient's kidney biopsy showed a mild mesangial hypercellularity (lupus nephritis class I). Mild intermediate fibrosis was observed in trichrome staining of tissue (Fig. 2).

The treatment with pulse methylprednisolone (1000 mg for three consecutive days) was started and continued with hydroxychloroquine and prednisolone (30 mg daily). Platelets were reduced to $100,000 / \mathrm{mm}^{3}$ and hemoglobin to $11 \mathrm{~g} / \mathrm{dL}$, but paresthesia, proteinuria, and edema continued. The patient has received monthly pulse doses of 1000-mg IV cyclophosphamide. The patient was discharged while being given hydroxychloroquine, prednisolone (10 mg daily), cyclophosphamide, gabapentin, and vitamin B (300 mg daily).

The patient was followed up after the 6-month. Paresthesia was improved. The laboratory tests (CBC, ESR, CRP, T3, T4) were normal and urine protein was $230 \mathrm{mg} /$ daily. Anti-double-stranded DNA antibody reduced to the normal range $(<35 \mathrm{IU} / \mathrm{mL})$.

\section{Discussion}

We presented a case of systemic lupus erythematosus associated with COVID-19 in a 39-year-old man. The patient developed COVID-19, and after about 2 months presented subsequently with manifestations of SLE. Recent studies have shown some clinical situations caused by chronic viral infections in patients with SLE. The researchers reported cases of SLE reactivated in human immunodeficiency virus (HIV) and hepatitis C virus $(\mathrm{HCV})$ patients after antiviral therapy. In addition, acute viral infections such as parvovirus B19 and EBV can mimic lupus, trigger lupus, or trigger SLE flares [2].

SARS-CoV-2 is a positive-sense single-stranded ribonucleic acid (RNA) virus that causes coronavirus disease 2019 (COVID-19). This acute viral infection is associated with a life-threatening respiratory disease [4]. We found a patient who showed clinical signs of lupus 2 months after getting COVID-19. Rajadhyaksha et al. reported a case of Dengue fever virus evolving into SLE and lupus nephritis. They found that dengue virus has triggered a dysfunctional immune response and resulted in the developing of autoimmunity, SLE, and lupus nephritis [3]. There are no published data on association of coronaviruses with SLE, but several studies have linked coronaviruses with another autoimmune disease such as multiple sclerosis (MS) and rheumatoid arthritis (RA). Joo et al. were observed an association between exposure to respiratory viral infections (including coronavirus, parainfluenza, metapneumovirus) for 6-7 weeks and the increase in incident RA. They concluded that coronaviruses may have the capacity to trigger RA [6]. A severe immune activation in response to SARS-CoV-2 infection has seen in some patients infected with COVID-19 that resulted
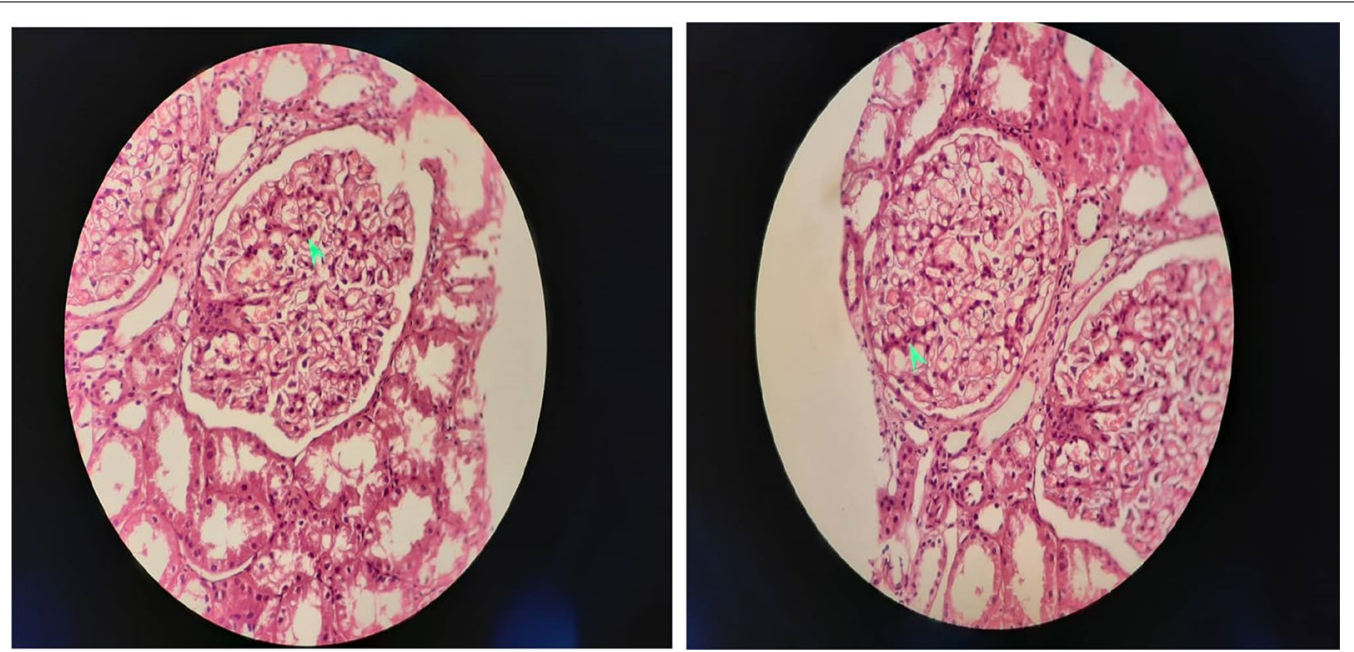

Fig. 2 The histopathology of kidney biopsy in the patient with SLE and COVID-19. Arrow shows inflammatory cell infiltration. A mild mesangial hypercellularity and mild fibrosis is seen in the background 
in acute respiratory distress syndrome, and a cytokine storm. SARS-CoV-2 increases interferon gamma, tumor necrosis factor- $\alpha$, macrophage inflammatory protein-1 alpha, IL-2, IL-6, IL-7, IL-10, in patients, that show a form of secondary hemophagocytic lymphohistiocytosis or macrophage activation syndrome (sHLH/MAS). Previous studies reported HLH in the background of SLE [8]. We found a case of SLE related to the new coronavirus (SARS-CoV-2). Acute infection with coronavirus may produce autoantibodies, such as anti-CCP antibodies and antinuclear antibodies [9].

\section{Conclusion}

Although single-case observations have limitations, the presented case report shows the possible role of novel coronavirus in the manifestation of SLE. Future reports can support or refute this hypothesis. We need to wait and see for more cases of autoimmune disorders to declare themselves following viral infections like COVID-19.

\section{Abbreviations}

CT: Computed tomography; COVID-19: Coronavirus disease 2019; SARS-CoV-2: Severe acute respiratory syndrome coronavirus; SLE: Systemic lupus erythematosus.

\section{Acknowledgements}

The authors would like to acknowledge the research deputy at Kashan University of Medical Sciences for the support.

\section{Authors' contributions}

SMMT and BZ conceived the idea and study design. MSH analyzed the data and wrote the manuscript. All authors read and approved the final manuscript.

\section{Funding}

This study was funded by Kashan University of Medical Sciences.

\section{Availability of data and materials}

No additional file is available for this study; all the data are included in the manuscript.

\section{Ethics approval and consent to participate}

This study was approved by Ethics Committee of Kashan University of Medical Sciences (IR.KAUMS.MEDNT.REC.1399.033). Each subject was assigned an informed written consent form.

\section{Consent for publication}

Written informed consent was obtained from the patient for publication of this case report and any accompanying images. A copy of the written consent is available for review by the Editor-in-Chief of this journal.

\section{Competing interests}

The authors declare that they have no competing interests.

\section{Author details}

${ }^{1}$ Autoimmune Diseases Research Center, Kashan University of Medical Sciences, Kashan, Iran. ${ }^{2}$ Department of Microbiology and Immunology, Faculty of Medicine, Kashan University of Medical Sciences, Kashan, Iran.

Received: 6 October 2020 Accepted: 11 November 2020

Published online: 25 January 2021

\section{References}

1. Zamani B, Shayestehpour M, Esfahanian F, Akbari H. The study of factors associated with pregnancy outcomes in patients with systemic lupus erythematosus. BMC Research Notes. 2020;13(1):185.

2. Ramos-Casals M. Viruses and lupus: the viral hypothesis. Lupus. 2008:17(3):163-5.

3. Rajadhyaksha A, Mehra S. Dengue fever evolving into systemic lupus erythematosus and lupus nephritis: a case report. Lupus. 2012;21(9):999-1002

4. Bozzalla Cassione E, Zanframundo G, Biglia A, Codullo V, Montecucco C, Cavagna L. COVID-19 infection in a northern-Italian cohort of systemic lupus erythematosus assessed by telemedicine. Ann Rheum Dis. 2020:79:1382-3.

5. Sun X, Wang T, Cai D, Hu Z, Chen J, Liao H, et al. Cytokine storm intervention in the early stages of COVID-19 pneumonia. Cytokine Growth Factor Rev. 2020;53:38-42.

6. Joo YB, Lim YH, Kim KJ, Park KS, Park YJ. Respiratory viral infections and the risk of rheumatoid arthritis. Arthritis Res Ther. 2019;21(1):199.

7. Gartshteyn Y, Askanase AD, Schmidt NM, Bernstein EJ, Khalili L, Drolet R, et al. COVID-19 and systemic lupus erythematosus: a case series. Lancet Rheumatol. 2020;2(8):e452-e454.

8. Sawalha AH, Manzi S. Coronavirus disease-2019: implication for the care and management of patients with systemic lupus erythematosus. Eur J Rheumatol. 2020;7(Suppl 2):S117-S120.

9. Gao Z-W, Wang X, Lin F, Dong K. The correlation between SARS-CoV-2 infection and rheumatic disease. Autoimmun Rev. 2020;19(7):102557.

\section{Publisher's Note}

Springer Nature remains neutral with regard to jurisdictional claims in published maps and institutional affiliations.

Ready to submit your research? Choose BMC and benefit from:

- fast, convenient online submission

- thorough peer review by experienced researchers in your field

- rapid publication on acceptance

- support for research data, including large and complex data types

- gold Open Access which fosters wider collaboration and increased citations

- maximum visibility for your research: over 100M website views per year

At $\mathrm{BMC}$, research is always in progress.

Learn more biomedcentral.com/submissions 